\title{
COLOR CHANGES OF WOOD FROM Pinus taeda AND Schizolobium parahybum TREATED BY in situ POLYMERIZATION OF METHYL METHACRYLATE USING CROSS-LINKERS
}

\author{
Bruno D. Mattos ${ }^{1}$, André L. Missio ${ }^{2}$, Pedro H.G de Cademartori', Darci A. Gatto ${ }^{2,4}$, \\ Washington L. E. Magalhães ${ }^{1,4}$
}

\begin{abstract}
The aim of this study was to evaluate the colorimetric properties of Pinus taeda and Schizolobium parahybum woods treated by in situ polymerization. The wood samples were impregnated in a vacuum/ pressure system and polymerized in an oven at $90^{\circ} \mathrm{C}$ for $10 \mathrm{~h}$, using benzoyl peroxide at $1,5 \mathrm{wt} \%$ as the catalyst. The treatments were characterized using attenuated total reflectance infrared (ATRIR) spectroscopy and weight percentage gain (WPG). The color evaluation was performed using $C I E L * a * b *$ concepts, specular gloss, and UV-Visible spectrophotometry. Treated woods showed increases in band intensity related to polymers $\left(1730,1460\right.$ and $\left.1145 \mathrm{~cm}^{-1}\right)$, and WPG ranged from 39 to $164 \%$, depending of the wood species and treatments. Lightness decreased, while the Chroma, gloss and the color coordinates increased. A darkening of the all treated samples was observed, and confirmed by the decrease in the reflectance intensity between 400 and $700 \mathrm{~nm}$.
\end{abstract}

Keywords: $C I E L^{*} a * b^{*}$, free radical polymerization, heat catalyst, UV-Vis, wood-polymer composites.

\section{INTRODUCTION}

Wood color is related to non-structural chemicals present in the xylem such as polyphenols, flavonoids, stilbenes and quinones. The variations in these substances gives colors to wood from different species.

According to Sandoval-Torres et al. (2010), unsaturated chemical bonds present in these substances can be easily transferred to a chemically excited state with a minimum amount of energy - these groups are named chromophores. The chromophores are functional groups that provide color to the materials because they are able to absorb ultraviolet and/or visible radiation (Loureiro et al. 2010). Furthermore, a functional group containing one isolated pair of electrons, such as $-\mathrm{OH}, \mathrm{COOH}$ or $-\mathrm{OR}$ is an auxochrome. These compounds can assist in the action of the chromophore groups by means of intensification or absorption of light at longer wavelengths, which correspond to the reddish color characteristic of wood (Hon and Shiraishi 1991).

\footnotetext{
${ }^{1}$ Integrated program in Engineering \& Materials Science (PIPE), Federal University of Paraná, Polytechnic Centre, Curitiba, Brazil.

${ }^{2}$ Forestry Engineering (PPGEF), Forest Products Laboratory, Centre for Rural Sciences, Federal University of Santa Maria. Santa Maria, Brazil.

${ }^{3}$ Wood and Forestry Science Center (PPGEF), Federal University of Paraná, Curitiba, Brazil.

${ }^{4}$ Embrapa Forestry, Colombo, Parana, Brazil.

"Corresponding author: darcigatto@pq.cnpq.br

Received: 01.01.2014 Accepted: 14.11.2015
} 
Wood color is an important factor for aesthetic purposes, and, in some cases, can influence the market value of this material (Rosu et al. 2010). Wood and wood-based products can be found in offices, houses and building construction. In such places, wood is used as furniture, decorative panels, flooring, doors, arches, stairs, sculptures or handicrafts, which create a pleasant environment, especially due to the nature of wood and its aesthetically soft look.

To stabilize or modify the color of wood, many treatments are commonly carried out using high temperatures and steam (Cademartori et al. 2014, Cademartori et al. 2013, Cermák and Dejmal 2013, Garcia et al. 2014, Hu et al. 2012, Kačíková et al. 2013). Thermo-mechanical or thermo-hydromechanical densification also can be used to modify the color of wood (Bekhta et al. 2014, Diouf et al. 2011). Nevertheless, these treatments always result in a similar pattern, i.e., a strong darkening of the samples, regardless of the wood species, and degradation of wood chemical constituents during heat or mechanical processes.

On the other hand, treatments of wood by in situ polymerization method have been carried out to enhance physical, biological and mechanical properties (Baysal et al. 2007, Hadi et al. 2013, Li et al. 2012), and promising results have been achieved. Nevertheless, not much is known about the colorimetric properties of these materials. Furthermore, studies on the topic are scarce (Mamiński et al. 2013), even considering the potential applications of these materials for commercial aesthetic products.

The quantitative measurement of color changes in wood is essentially performed with an efficient technique regulated by the Commission International de L'Eclairage (CIE), whereby the parameters of lightness $\left(L^{*}\right)$, chromaticity coordinates $\left(a^{*}\right.$ and $\left.b^{*}\right)$, chroma $\left(C^{*}\right)$ and hue angle $\left(h^{*}\right)$, can be measured. The CIEL $a^{*} b^{*}$ method has been widely applied in other research to evaluate changes in wood color (Cademartori et al. 2014, Hu et al. 2012, Mamiński et al. 2013, Tuong and Li 2010), though UVVisible spectrophotometry and specular gloss tests are also good tools to assist in color evaluation and, consequently, to provide more accurate information about the aesthetic properties of wood and its composites (Butylina et al. 2013, Obaid et al. 2013).

The aim of this study was to evaluate the color properties of composites prepared by in situ polymerization treatment of Pinus taeda and Schizolobium parahybum wood, using methyl methacrylate (MMA) as the base monomer, and glycidyl methacrylate (GMA) and methacrylic acid (MAA) as crosslinkers and coupling agents.

\section{MATERIALS AND METHODS}

\section{Materials}

Three flatsawn heartwood planks $\left(25 \times 25 \times 270 \mathrm{~cm}^{3}\right)$ including the pith of Loblolly pine (Pinus taeda) were provided by a local sawmill (Madarco S.A., Pelotas-RS, Brazil). Three heartwood planks of Guapuruvu (Schizolobium parahyba) including the pith and with straight grain $\left(8 \times 50 \times 200 \mathrm{~cm}^{3}\right)$ were obtained from an experimental forest plantation in Southern Brazil (21 years old). From these materials, samples were cut into small defect-free pieces with dimensions of 1 x $5 \times 5 \mathrm{~cm}^{3}$ (thickness, width and length).

Methyl methacrylate (MMA) was used as the main monomer. Glycidyl methacrylate (GMA) and methacrylic acid (MAA) were used as additives (cross-linker and coupling). All monomers were purchased from Sigma Aldrich and used as received. Benzoyl peroxide (BPO) from Vetec Química Fina was selected as the heat catalyst.

\section{In situ polymerization treatments}

The samples were oven-dried at $90 \pm 2^{\circ} \mathrm{C}$ until reaching constant mass ( $\sim 48$ hours) and then cooled in a desiccator with silica gel in order to avoid water vapor absorption until the impregnation step. The monomeric solutions were prepared according to Table 1; 1,5 wt.\% of benzoyl peroxide was added, and homogenized in the solution using a magnetic stirrer. 
Table 1. Parameters of in situ polymerization treatments for each wood.

\begin{tabular}{lcccc}
\hline \multirow{2}{*}{ Treatment } & \multicolumn{3}{c}{$\mathrm{ml}$} & $\mathrm{g}$ \\
\cline { 2 - 5 } & MMA & GMA & MAA & BPO \\
\hline W (Control) & - & - & - & - \\
W/M & 1000 & - & - & 15 \\
W/M:G (2:1) & 665 & 335 & - & 15 \\
W/M:G (3:1) & 750 & 250 & - & 15 \\
W/M:A (2:1) & 665 & - & 335 & 15 \\
W/M:A (3:1) & 750 & - & 250 & 15 \\
\hline
\end{tabular}

$\mathrm{MMA}=$ methyl methacrylate; $\mathrm{GMA}=$ glycidyl methacrylate; $\mathrm{MAA}=$ methacrylic acid $; \mathrm{BPO}=$ Benzoyl peroxide.

Half of a stainless steel cylinder (2L) was filled with the samples and vacuumed at 800 mbar for 30 min. Subsequently, $1 \mathrm{~L}$ of the solution (Table 1) was released into the cylinder and the cylinder was pressurized by air compression at 6,08 bar for $1 \mathrm{~h}$. Samples were then taken out of the cylinder and excesses of the solution were wiped from the samples' surface. Lastly, all the samples were wrapped in aluminum foil and heat polymerized at $90 \pm 2^{\circ} \mathrm{C}$ for $10 \mathrm{~h}$. This step was followed by drying at the same temperature for another $24 \mathrm{~h}$.

\section{ATR-IR Evaluation}

Fourier Transform Infrared spectra was qualitatively used to evaluate the chemical structure modification of treated woods using monomer and untreated wood as references. The spectra were acquired in a Nicolet Nexus 570 spectrometer, equipped with an attenuated total reflectance device (ATR-IR), and configured at a resolution of $4 \mathrm{~cm}^{-1}$ for 32 scans in the range of $700 \mathrm{~cm}^{-1}$ to $4000 \mathrm{~cm}^{-1}$. Alignment of the light equipment, and the background spectra was performed before all the tests.

\section{Weight percentage gain}

The weight percentage gain (WPG) after the treatments was calculated using equation 1, as previously mentioned in other studies (Devi and Maji 2013b, Ding et al. 2013, Hazarika and Maji 2013, Islam et al. 2013).

$$
W P G=\left[\left(W_{p}-W_{0}\right) / W_{0}\right] \times 100
$$
treatment.

where: $\mathrm{W}_{\mathrm{p}}=$ oven-dried weight of sample after the treatment; $\mathrm{m}_{0}=$ weight of sample before the

\section{Scanning electron microscopy characterization}

Before the acquisition of the images, the cross-sections of the samples were prepared with a microtome Leica model SM2010R. After the surface preparation, the samples were oven-dried at $103 \pm 2^{\circ} \mathrm{C}$ until reaching constant weight. The images were captured with magnification of $1 \mathrm{k}$ through a Shimadzu scanning electron microscopy, model SSX 550 Superscan.

\section{$C I E L * a * b *$ color evaluation}

The color was measured using a Konica Minolta CR-400 equipment, configured to use a D65 light source and $10^{\circ}$ of observation angle, as described by the Commission Internationale de L'éclairage 
(CIEL*a*b* standard). Before measurement, the equipment was calibrated using the spectral reflectance of a white calibration plate as the standard. Ten replicates for each treatment were collected to measure the parameters of lightness $\left(L^{*}\right)$, and green-red $\left(a^{*}\right)$ and blue-yellow $\left(b^{*}\right)$ chromatic coordinates. Chroma $\left(C^{*}\right)$, hue angle $\left(h^{*}\right)$ and color variation parameters of $\Delta \mathrm{E}, \Delta L^{*}, \Delta a^{*}$ and $\Delta b^{*}$ were obtained through equations 2 to 7 , respectively.

$$
\begin{gathered}
C^{*}=\left(a^{*^{2}}+b^{*^{2}}\right)^{1 / 2} \\
h=\operatorname{tang}^{-1}\left(b^{*} / a^{*}\right) \\
\Delta E=\left(\Delta L^{* 2}+\Delta a^{*^{2}}+\Delta b^{*^{2}}\right)^{1 / 2} \\
\Delta L^{*}=L^{*}{ }_{t}-L^{*}{ }_{u t} \\
\Delta a^{*}=a^{*}{ }_{t}-a^{*}{ }_{u t} \\
\Delta b^{*}=b^{*}{ }_{t}-b^{*}{ }_{u t}
\end{gathered}
$$

$\Delta \mathrm{E}, \Delta L^{*}, \Delta a^{*}, \Delta b^{*}=$ color difference, variation of lightness, variation of green-red chromatic coordinate and variation of blue-yellow chromatic coordinate, respectively; $\mathrm{t}=$ treated; $\mathrm{ut}=$ untreated.

\section{Specular gloss determination}

The reflected specular gloss at an incidence angle of $85^{\circ}$ was measured in the radial section along the grain of the samples, according to ASTM D 523-08 (2008). For this, a Konica-Minolta Multi Gloss 268 plus equipment was used. Ten measurements for each treatment were performed. The results were expressed in gloss units, which are related to a standard black glass surface highly polished with gloss, valued near 100 .

\section{UV-visible spectrophotometry}

Tests of reflectance ranging from 200 to $700 \mathrm{~nm}$ were performed using a Shimadzu UV-Vis-NIR 3600 equipment to assist the color evaluation. The spectra were the average of three measurements for each sample. The measurements were performed in the radial section surface of the solid samples.

\section{RESULTS AND DISCUSSION}

\section{Treatment evaluation}

Expected crosslinking and coupling reactions between the copolymers formed from the insertion of GMA and MAA and the wood cell wall happened via epoxy ring and - $\mathrm{COOH}$ with free $\mathrm{OH}$ groups, respectively (Li et al. 2012, Zhang et al. 2013).

Figure 1 shows the ATR-IR spectra of untreated and treated woods by in situ polymerization, and Table 2 details the ratio of peaks corresponding to the polymeric chemical structures. Typical infrared peaks related to methacrylate and methacrylic polymer structures were observed at 1145, 1460 and 
$1730 \mathrm{~cm}^{-1}$, which correspond to C-O stretching ether group, C-H deformation and carbonyl groups $(\mathrm{C}=\mathrm{O})$, respectively (Li et al. 2013, Zhang et al. 2013).

- Control - W/M -W/M:G 2:1 - W/M:G 3:1 - W/M:A 2:1 - W/M:A 3:1
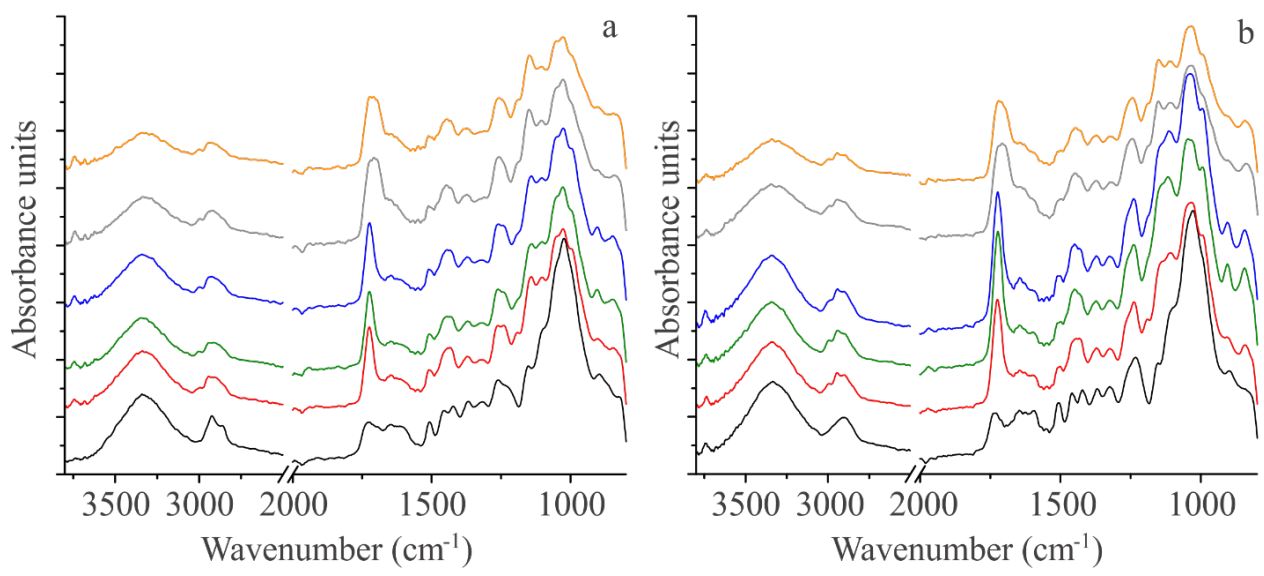

Figure 1. ATR-IR spectra of pine (a) and guapuruvu (b) treated woods.

The peak at $1050 \mathrm{~cm}^{-1}$ was used as the internal standard to obtain the ratios of peaks related to the chemical structures of the polymers. This peak corresponds to $\mathrm{C}-\mathrm{H}$ in plane deformation and symmetrical $\mathrm{C}-\mathrm{O}$ stretching of cellulose - two very unreactive structures of wood in chemical or thermal treatments (Chen et al. 2012, Schwanninger et al. 2004). No changes were observed in these regions after in situ polymerization treatments of wood (Devi and Maji 2013a, Hazarika et al. 2014, Islam et al. 2011).

An increase in $\mathrm{I}_{1730 / 1050}$ and $\mathrm{I}_{1460 / 1050}$ ratios was evident in the treated woods (Table 2), and proves that polymers and copolymers were present/synthetized inside of the two woods. Both decreases in $\mathrm{I}_{3350 / 1050}$ and the increase in $\mathrm{I}_{1145 / 1050}$ for treatments with GMA and MAA were due to the partial substitution of wood hydroxyl groups by new ether bonds after the in situ polymerization - W/M:A treatments presented the lowest ratio of $3350 \mathrm{~cm}^{-1}$ and the highest ratio of $1145 \mathrm{~cm}^{-1}$ (Table 2).

Table 2. Ratio of peaks corresponding to the polymeric chemical structures.

\begin{tabular}{cccccc}
\hline Wood & Sample & $\mathrm{I}_{1730 / 1050}$ & $\mathrm{I}_{1145 / 1050}$ & $\mathrm{I}_{1460 / 1050}$ & $\mathrm{I}_{3350 / 1050}$ \\
\hline & Control & 0.215 & 0.416 & 0.293 & 0.338 \\
Guapuruvu & W/M & 0.506 & 0.728 & 0.344 & 0.351 \\
(Schizolobium & W/M:G 2:1 & 0.529 & 0.801 & 0.339 & 0.306 \\
parahybum) & W/M:G 3:1 & 0.521 & 0.771 & 0.359 & 0.322 \\
& W/M:A 2:1 & 0.477 & 0.761 & 0.377 & 0.305 \\
& W/M:A 3:1 & 0.496 & 0.809 & 0.365 & 0.318 \\
\hline & Control & 0.227 & 0.499 & 0.278 & 0.357 \\
Wine & W/M & 0.449 & 0.772 & 0.340 & 0.359 \\
W/M:G 2:1 & 0.433 & 0.741 & 0.324 & 0.343 \\
& W/M:G 3:1 & 0.462 & 0.777 & 0.340 & 0.345 \\
& W/M:A 2:1 & 0.498 & 0.867 & 0.391 & 0.342 \\
& W/M:A 3:1 & 0.536 & 0.895 & 0.406 & 0.336 \\
\hline
\end{tabular}

The polymers and copolymers formed inside the woods reached high loading levels, mainly in the 
treatments with guapuruvu wood. Differences in density and porosity of guapuruvu $\left(270 \mathrm{~kg} \mathrm{~m}^{-3}\right.$ and $80 \%$, respectively) and pine (520 $\mathrm{m} \mathrm{kg} \mathrm{m}^{-3}$ and $63 \%$ ) woods resulted in WPG values substantially higher for the guapuruvu wood (Figure 2). Therefore, anatomical differences between hard and softwood mainly due to vestured pits for guapuruvu and bordered pits for pine - lead to differences in WPG.

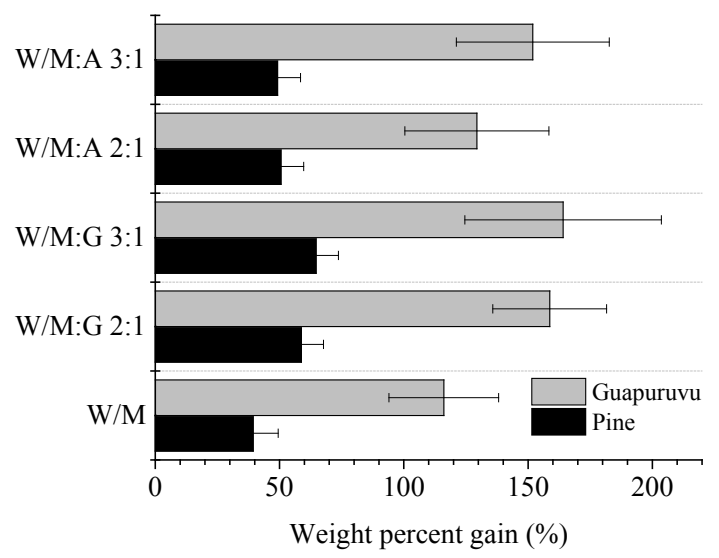

Figure 2. Weight percentage gain of two woods Guapuruvu (Schizolobium parahybum) and Pine (Pinus taeda)) after in situ polymerization treatments.

The W/M treatment presented the lowest WPG, while the W/M:G (2:1) treatment showed the highest value of WPG. A lack of adhesion of the poly (MMA) with the wood cell wall's internal surface explains the lowest WPG for the W/M treatments. Nevertheless, after insertion of the polar additive - such as the GMA and MAA monomers - WPG increased, due to the higher compatibility between polymeric reinforcement and the wood (Figure 3c, 3d, 3g, and 3h). Other authors reported similar results using different polymers and wood (Devi and Maji, 2013b, Islam et al. 2011, Li et al. 2012).

W/M treatments for both wood (Figure $3 \mathrm{~b}$ and $3 \mathrm{f}$ ) showed a lack of adhesion of poly (MMA) to the wood cell wall's internal surface, even when the lumen were completely filled. Due to shrinkage of the poly (MMA) after polymerization, clearance space between the polymer and the cell wall became visible.

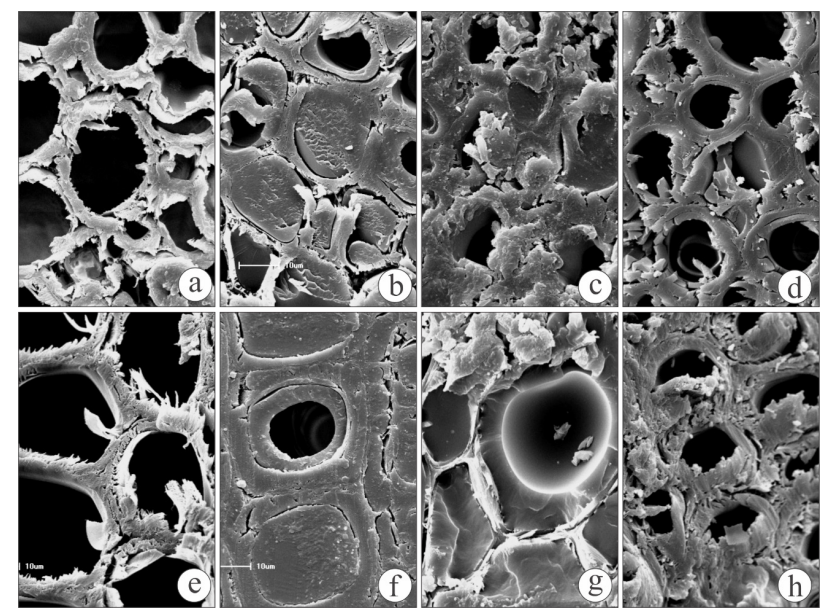

Figure 3. Morphology of the untreated woods and wood/polymer composites prepared by in situ polymerization $(\mathrm{a}=$ control, $\mathrm{b}=\mathrm{W} / \mathrm{M}, \mathrm{c}=\mathrm{W} / \mathrm{M}: \mathrm{G} 2: 1$ and $\mathrm{d}=\mathrm{W} / \mathrm{M}: \mathrm{A} 2: 1$ for guapuruvu (Schizolobium parahybum) wood; $\mathrm{e}=$ control, $\mathrm{f}=\mathrm{W} / \mathrm{M}, \mathrm{g}=\mathrm{W} / \mathrm{M}: \mathrm{G} 2: 1$ and $\mathrm{h}=\mathrm{W} / \mathrm{M}: \mathrm{A}$ 2:1 for pine wood). 
In the crosslinked treated wood (Figure $3 \mathrm{c}, 3 \mathrm{~d}, 3 \mathrm{~g}$ and $3 \mathrm{~h}$ ), filling the cellular elements of both wood was not completed, which occurred because a fraction of the polymer is now inside of the wood cell wall. Penetration and polymer adhesion - coating - to the cell wall was due to the reaction between the carboxyl groups of the MAA or epoxy ring of the GMA with reactive $\mathrm{OH}$ from the wood (Mattos et al. 2014).

\section{Color evaluation}

The natural color of guapuruvu and pine wood was yellow and blanched pink (salmon) (Figure 4). Color changes were observed after in situ polymerization treatments. Nevertheless, these changes were less intense than previously found in other types of treatments such as thermal modification (Cademartori et al. 2014, Hu et al. 2012).

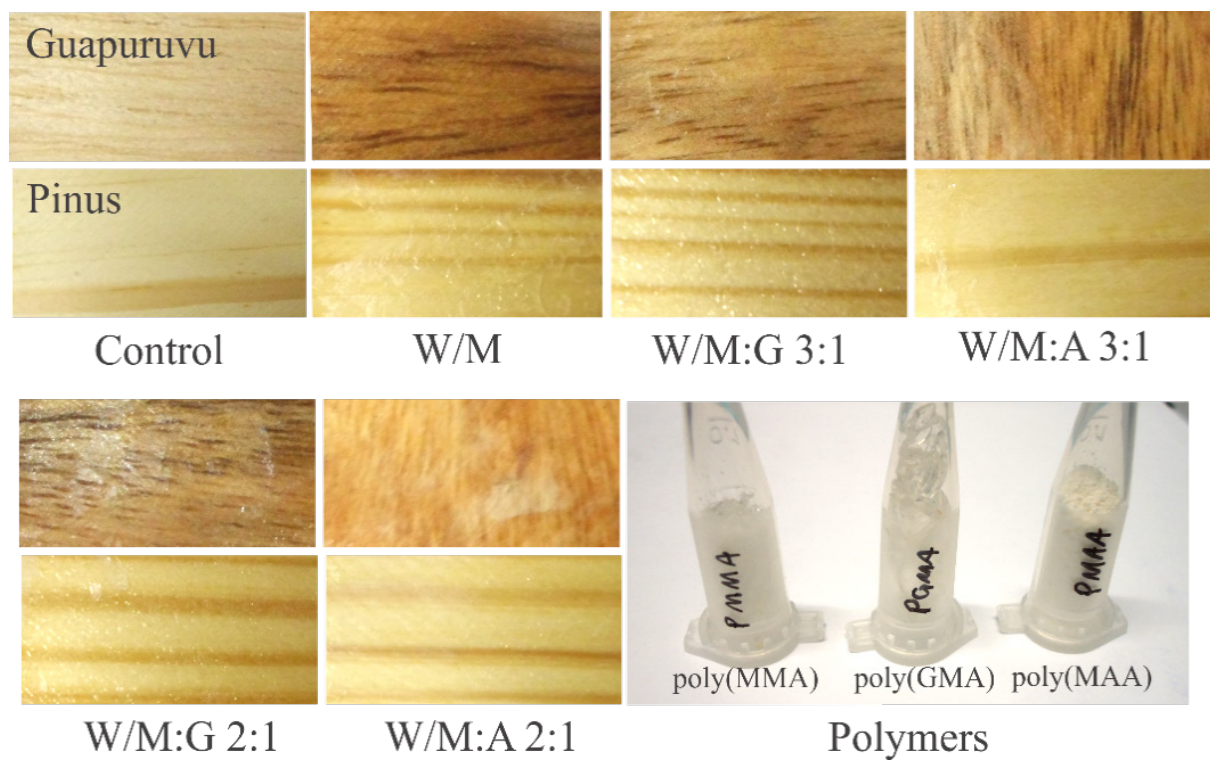

Figure 4. Visual aspects of raw materials and guapuruvu (Schizolobium parahybum) and pine (Pinus taeda) treated wood.

CIEL*a*b* parameters significantly varied after the treatments (Table 3 ). A decrement in the lightness of the samples $\left(L^{*}\right)$ was observed, which resulted in a darkening of the wood. Guapuruvu wood presented the highest decrement of lightness. A decrement of $\mathrm{L}^{*}$ after in situ polymerization treatments was also observed by Mamiński et al. (2013), who treated beech wood with butyl acrylate and butyl methacrylate.

Both chromatic coordinates $a^{*}$, and $b^{*}$ of guapuruvu and pine wood increased after the in situ polymerization treatments. The increase of $a^{*}$ in guapuruvu wood was twice higher as that of the pine wood (Table 3). An increment of $a^{*}$ denotes a reinforcement of the reddish tones in the guapuruvu treated wood.

The variation of $a^{*}$ in the pine wood treatments did not represent any specific modification due to the absence of red tones in the samples. Nevertheless, increase of both chromatic coordinates $\left(a^{*}\right.$ and $b^{*}$ ) infers a color change from opaque yellow to vivid yellow, nearly orange (Konica Minolta, 2007). The highest increase of $a^{*}$ and $b^{*}$ was observed in W/M and W/M:G (2:1) treatments, as can be seen through the results of $\Delta a^{*}$ and $\Delta b^{*}$ (Table 3). Chroma increases with increased $a^{*}$ and $b^{*}$. Also, decrease of the hue angle were associated to the intensification of the red tones of wood (Figure 5.) 
Table 3. Color differences of the treated wood in relation to the untreated wood.

\begin{tabular}{cccccccc}
\hline Wood & Treatments & $\Delta \mathrm{L}^{*}$ & $\Delta \mathrm{a}^{*}$ & $\Delta \mathrm{b}^{*}$ & $\Delta E$ & $\Delta$ Chroma & Ahue \\
\hline & W/M & -15.2 & 7.2 & 12.2 & 20.7 & 13.8 & -6.3 \\
Guapuruvu & W/M:G 2:1 & -22.4 & 8.0 & 8.5 & 25.3 & 10.8 & -10.5 \\
(Schizolobium & W/M:G 3:1 & -11.7 & 4.8 & 10.9 & 16.7 & 11.9 & -3.4 \\
parahybum) & W/M:A 2:1 & -10.8 & 5.7 & 9.4 & 15.4 & 10.9 & -5.5 \\
& W/M:A 3:1 & -12.6 & 5.5 & 9.0 & 16.5 & 10.3 & -5.6 \\
\hline W/M & -7.2 & 2.5 & 5.8 & 9.5 & 6.1 & -3.2 \\
Pine & W/M:G 2:1 & -7.9 & 2.8 & 5.2 & 9.8 & 5.6 & -3.5 \\
(Pinus taeda) & W/M:G 3:1 & -6.3 & 1.5 & 4.1 & 7.6 & 4.2 & -2.0 \\
& W/M:A 2:1 & -1.9 & 1.1 & 3.7 & 4.4 & 3.8 & -1.3 \\
& W/M:A 3:1 & -3.9 & 1.4 & 5.5 & 6.9 & 5.6 & -1.5 \\
\hline
\end{tabular}

The behavior presented in Table 3 (increase of $L^{*}$ and decrease of both $a^{*}$ and $b^{*}$ ) typically does not occur in other treatments performed to stabilize wood color - normally, a decrease of $L^{*}, a^{*}$ and $b^{*}$ is observed (Cademartori et al. 2014, Tuong and Li 2010). Decrease of CIEL*a* $b^{*}$ parameters are associated mainly with chemical modifications caused by the high temperatures in the thermal treatments, or thermochemical reactions involved in chemical treatments (Mattos et al. 2015). However, high temperatures were not necessary to polymerize methacrylate and methacrylic monomers inside the wood. The Lightness vs. chromaticity diagram shows that the lowest initial $\mathrm{C}^{*}$ of the untreated samples resulted in the highest color changes after the treatments (Figure 5).

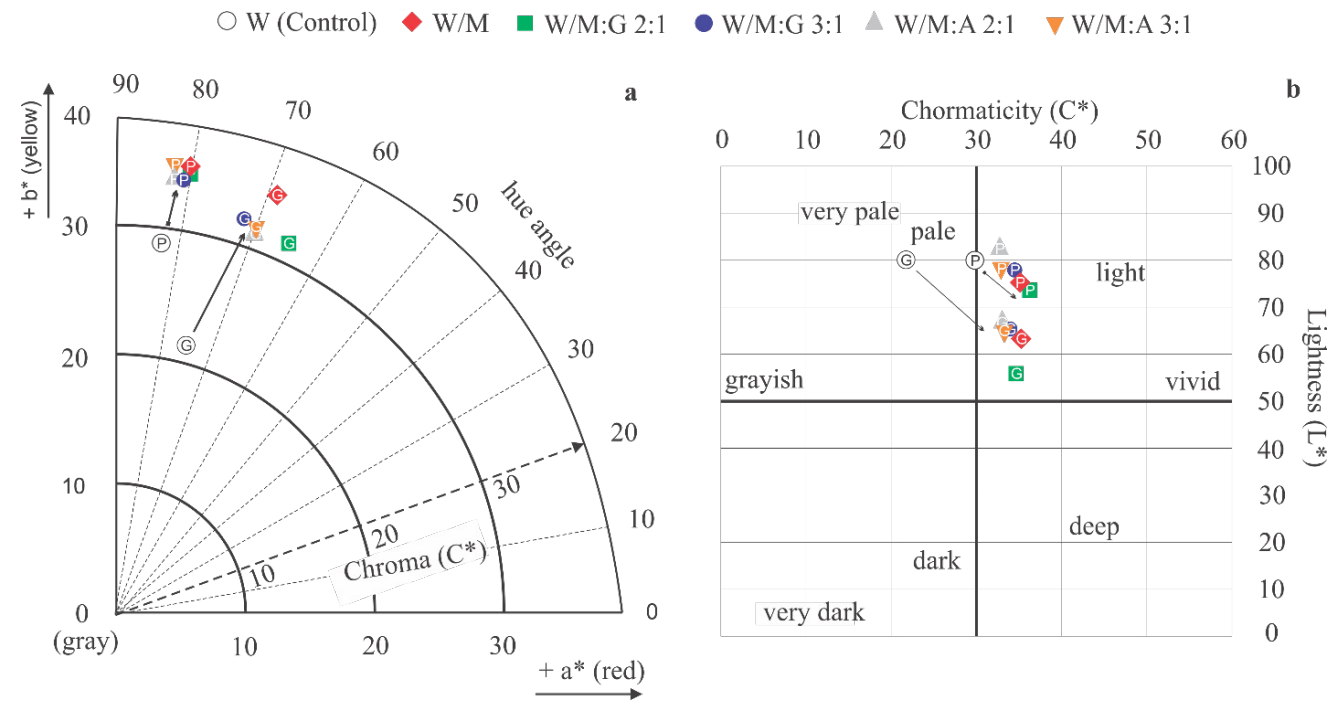

Figure 5. Hue angle displacement diagram (a) and lightness vs. chromaticity diagram (b).

The hue angle displacement and lightness vs. chromaticity diagrams clearly showed a color dislocation from pale tones to light and vivid tones (loss of grayish tones) in two woods after the treatments - which was more pronounced in guapuruvu wood. Higher darkening of guapuruvu treated wood was observed, which resulted in more mild colors, and even increased gloss (Table 4). 
The W/M:G 3:1 treatment in guapuruvu wood was the nearest to the dull zone in the chromaticity diagram, even when it presented the highest specular gloss (7,92; Table 4). On the other hand, the highest reduction of $L^{*}\left(\Delta \mathrm{L}^{*}\right.$ of $\left.-22,4\right)$ was observed in this same treatment, i.e., $L^{*}$ was more significant than the gloss to determine the vivacity of colors of the wood treated samples.

Overall, significant increases in the specular gloss of the samples were observed after in situ polymerization treatments, with exception of the W/M:A 2:1 treatment (Table 4).

Table 4. Specular gloss of untreated and treated woods

\begin{tabular}{|c|c|c|c|c|c|c|c|}
\hline Wood & Control & $\mathrm{W} / \mathrm{M}$ & $\begin{array}{c}\text { W/M:G } \\
2: 1\end{array}$ & $\begin{array}{c}\text { W/M:G } \\
3: 1\end{array}$ & $\begin{array}{c}\text { W/M:A } \\
2: 1\end{array}$ & $\begin{array}{c}\text { W/M:A } \\
3: 1\end{array}$ & F-ratio \\
\hline $\begin{array}{c}\text { Pine } \\
\text { (Pinus taeda) }\end{array}$ & $\begin{array}{l}0.18 \mathrm{a} \\
(0.06)\end{array}$ & $\begin{array}{l}2.45 \mathrm{~d} \\
(0.31)\end{array}$ & $\begin{array}{l}3.55 \mathrm{e} \\
(0.34)\end{array}$ & $\begin{array}{l}1.97 \mathrm{c} \\
(0.57)\end{array}$ & $\begin{array}{l}0.3 \mathrm{ab} \\
(0.07)\end{array}$ & $\begin{array}{l}0.49 \mathrm{~b} \\
(0.18)\end{array}$ & $207.44^{*}$ \\
\hline $\begin{array}{c}\text { Guapuruvu } \\
\text { (Schizolobium } \\
\text { parahybum) }\end{array}$ & $\begin{array}{l}2.03 \mathrm{~b} \\
(0.49)\end{array}$ & $\begin{array}{l}3.45 \mathrm{c} \\
(0.79)\end{array}$ & $\begin{array}{l}7.92 \mathrm{e} \\
(1.84)\end{array}$ & $\begin{array}{l}6.40 \mathrm{~d} \\
(0.73)\end{array}$ & $\begin{array}{l}1.22 \mathrm{a} \\
(0.06)\end{array}$ & $\begin{array}{l}2.2 \mathrm{~b} \\
(0.31)\end{array}$ & $90.47 *$ \\
\hline
\end{tabular}

The treatments with methacrylic acid (MAA) presented the lowest improvement in the specular gloss, mainly because the copolymer poly(MMA-co-MAA) formed is whitish and very pale, while poly(MMA-co-GMA) has a naturally high gloss, similar to poly(MAA) and poly(GMA) (Figure 4).

The reflectance curves in the visible region confirm the color changes in both treated wood. In summary, both untreated and treated wood show low reflectance until 400-500nm, followed by high reflectance at longer wavenumbers (Figure 6). This reflectance pattern was also observed by Obaid et al. (2013) in polystyrene-wood composites and by Butylina et al. (2013) in composites prepared with polypropylene and wood particles.
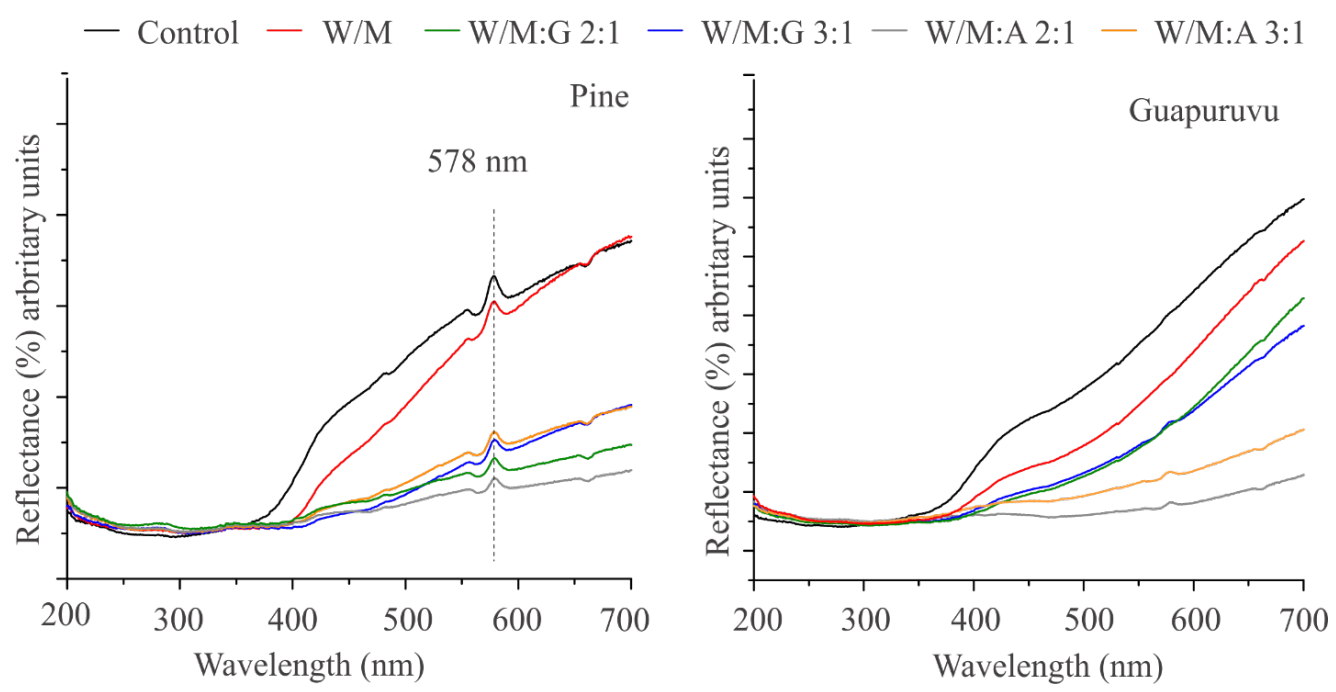

Figure 6. UV-Vis reflectance curves for untreated and treated wood: Guapuruvu (Schizolobium parahybum) and Pine (Pinus taeda).

According to Pandey and Vuorinen (2008), the intense absorption below $400 \mathrm{~nm}$ occurs due to the 
large amount of chemical chromophore structures, mainly carbonyl groups in lignin, which absorb light in this spectral band. A peak at $578 \mathrm{~nm}$ related to the yellow color was observed in both untreated and treated pine wood. On the other hand, no characteristic peak related to the color of guapuruvu wood was verified, mainly because its blanched pink color is not well-defined in the electromagnetic spectra.

After all the treatments, a decrement of the reflectance in the visible range was observed, which was more pronounced in the W/M:G and W/M:A treatments. This decrease is due to the new chemical groups from polymers, which are able to absorb light in the visible range. Another reason is the darkening of the samples after the treatments, as found by Chen et al. (2012) and Huang et al. (2012). These authors observed an increase in absorption for different wavenumbers in the visible region due to the darkening of wood after heat treatments.

A peak at $578 \mathrm{~nm}$ in the pine treated wood indicated the maintenance of the original color. Nevertheless, as previously verified in the $C I E L^{*} a * b *$ evaluation, a darkening of the samples was observed, resulting in treated wood with lower reflectance at regions above $500 \mathrm{~nm}$. This behavior was also observed for guapuruvu wood.

\section{CONCLUSIONS}

Regardless of the treatment used, guapuruvu (Schizolobium parahybum) treated wood was more susceptible to colorimetric changes than pine wood (Pinus taeda). The lightness decreased significantly and the dullness increased. However, most of the treated woods presented an aspect of glossy surface.

The treatments with methacrylic acid (MAA) resulted in the lowest improvements in the specular gloss, and in the lowest changes in both chroma and lightness. L* was more influent than the specular gloss to change the vivacity of wood colors after in situ polymerization treatments.

Decrease in the reflectance at $400-700 \mathrm{~nm}$ confirmed the darkening of treated woods.

\section{ACKNOWLEDGEMENTS}

The authors wish to thank CNPq (National Counsel of Technological and Scientific Development), CAPES (Coordination for the Improvement of Higher Education Personnel) and Araucária Foundation for the fellowships, and we also thank Ms. Bia Carneiro for the professional support with the English language.

\section{REFERENCES}

American Society of Testing and Methods (ASTM). Standard Test Method for Specular Gloss. Philadelphia: ASTM. D 523-08, 2008.

Baysal, E.; Yalinkilic, M.K.; Altinok, M.; Sonmez, A.; Peker, H.; Colak, M. 2007. Some physical; biological; mechanical; and fire properties of wood polymer composite (WPC) pretreated with boric acid and borax mixture. Construction and Building Materials 21: 1879-1885.

Bekhta, P.; Proszyk, S.; Krystofiak, T. 2014. Colour in short-term thermo-mechanically densified veneer of various wood species. Eur J Wood Prod 72: 785-797.

Butylina, S.; Martikka, O.; Kärki, T. 2013. Thermal performance and optical properties of wood-polymer composites. Journal of Thermoplastic Composite Materials 26: 60-73. 
Cademartori; P.H.G.d.; Mattos; B.D.; Missio; A.L.; Gatto; D.A. 2014. Colour responses of two fast-growing hardwoods to thermal treatment. Materials Research 17(2):487-493.

Cademartori, P.H.G.; Schneid, E.; Gatto, D.A.; Martins-Stangerlin, D.; Beltrame, R. 2013. Thermal modification of Eucalyptus grandis wood: variation of colorimetric parameters. Maderas. Ciencia y tecnología 15: 57-64.

Cermák, P.; Dejmal, A. 2013. The effect of heat and ammonia treatment on colour response of oak wood (Quercus robur) and comparison of some physical and mechanical properties. Maderas. Ciencia y tecnología 15: 375-389.

Chen, Y.; Fan, Y.; Gao, J.; Stark, N.M. 2012. The effect of heat treatment on the chemical and colour change of black locust (Robinia pseudoacacia) wood flour. BioResource 7: 1157-1170.

Devi, R.; Maji, T. 2013a. Effect of nanofillers on flame retardancy; chemical resistance; antibacterial properties and biodegradation of wood/styrene acrylonitrile co-polymer composites. Wood Sci Technol 47: 1135-1152.

Devi, R.R.; Maji, T.K. 2013b. In situ polymerized wood polymer composite: effect of additives and nanoclay on the thermal; mechanical properties. Materials Research 16: 954-963.

Ding; W.-D.; Koubaa; A.; Chaala; A. 2013. Mechanical properties of MMA-hardened hybrid poplar wood. Industrial Crops and Products 46: 304-310.

Diouf, P.N.; Stevanovic, T.; Cloutier, A.; Fang, C.H.; Blanchet, P.; Koubaa, A.; Mariotti; N. 2011. Effects of thermo-hygro-mechanical densification on the surface characteristics of trembling aspen and hybrid poplar wood veneers. Applied Surface Science 257: 3558-3564.

Garcia, R.A.; de Oliveira-Lopes, J.; do Nascimento, A.M.; de Figueiredo-Latorraca, J.V. 2014. Color stability of weathered heat-treated teak wood. Maderas. Ciencia y tecnología 16: 453-462.

Hadi, Y.S.; Rahayu, I.S.; Danu, S. 2013. Physical and mechanical properties of methyl methacrylate impregnated jabon wood. J Indian Acad Wood Sci 10(2):77-80.

Hazarika, A.; Maji, T.K. 2013. Effect of different crosslinkers on properties of melamine formaldehyde-furfuryl alcohol copolymer/montmorillonite impregnated softwood (Ficus hispida). Polymer Engineering \& Science 53: 1394-1404.

Hazarika, A.; Mandal, M.; Maji, T.K. 2014. Dynamic mechanical analysis; biodegradability and thermal stability of wood polymer nanocomposites. Composites Part B: Engineering 60: 568-576.

Hon, D.N.S.; Shiraishi, N. 1991. Wood and Cellulosic Chemistry. Inc.; New York.

Hu, C.; Jiang, G.; Xiao, M.; Zhou, J.; Yi, Z. 2012. Effects of heat treatment on water-soluble extractives and color changes of merbau heartwood. J Wood Sci 58: 465-469.

Huang; X.; Kocaefe, D.; Kocaefe, Y.; Boluk, Y.; Pichette, A. 2012. A spectrocolorimetric and chemical study on color modification of heat-treated wood during artificial weathering. Applied Surface Science 258: 5360-5369.

Islam, M.S.; Hamdan, S.; Hassan, A.; Talib, Z.A.; Sobuz, H. 2013. The chemical modification of tropical wood polymer composites. Journal of Composite Materials 48 (7): 783-789.

Islam, M.S.; Hamdan, S.; Jusoh, I.; Rahman, M.R.; Talib, Z.A. 2011. Dimensional Stability and Dynamic Young's Modulus of Tropical Light Hardwood Chemically Treated with Methyl Methacrylate in Combination with Hexamethylene Diisocyanate Cross-Linker. Industrial \& Engineering Chemistry Research 50: 3900-3906. 
Kačíková, D.; Kačík, F.; Čabalová, I.; Ďurkovič, J. 2013. Effects of thermal treatment on chemical; mechanical and colour traits in Norway spruce wood. Bioresource Technology 144: 669-674.

Konica Minolta. Precise color communication: color control from perception to instrumentation. Japan: Konica Minolta Sensing Inc, 2007.

Li, Y.; Wu, Q.; Li, J.; Liu, Y.; Wang, X.M.; Liu, Z. 2012. Improvement of dimensional stability of wood via combination treatment: swelling with maleic anhydride and grafting with glycidyl methacrylate and methyl methacrylate. Holzforschung 66(1):59-66.

Li, Y.; XiaoYing, D.; ZeGuang, L.; WanDa, J.; YiXing, L. 2013. Effect of polymer in situ synthesized from methyl methacrylate and styrene on the morphology. thermal behavior; and durability of wood. Journal of Applied Polymer Science 128: 13-20.

Loureiro, P.E.G.; Fernandes, A.J.S.; Carvalho, M.G.V.S.; Evtuguin, D.V. 2010. The assessment of chromophores in bleached cellulosic pulps employing UV-Raman spectroscopy. Carbohydrate Research 345: 1442-1451.

Mamiński, M.; Król, M.; McDonald, A.; McIlroy, D.; Niraula, I.; Czechowska, J.; Parzuchowski, P. 2013. Thermally initiated solvent-free radical modification of beech (Fagus sylvatica) wood. Wood Sci Technol 47: 1019-1031.

Mattos, B.; Lourençon, T.; Serrano, L.; Labidi, J.; Gatto, D. 2015. Chemical modification of fast-growing eucalyptus wood. Wood Sci Technol 49(2):273-288.

Mattos, B.; Serrano, L.; Gatto, D.; Magalhães, W.L.E.; Labidi, J. 2014. Thermochemical and hygroscopicity properties of pinewood treated by in situ copolymerisation with methacrylate monomers. Thermochimica Acta 596: 70-78.

Obaid, H.N.; Hadi, A.G.; Lafta, F.; Hashim, A. 2013. Optical Properties of (Polystyrene-Wood Buckthorn Peel) Composites. Agricultural Journal 8: 170-172.

Pandey, K.K.; Vuorinen, T. 2008. Comparative study of photodegradation of wood by a UV laser and a xenon light source. Polymer Degradation and Stability 93: 2138-2146.

Rosu, D.; Teaca, C.A.; Bodirlau, R.; Rosu, L. 2010. FTIR and color change of the modified wood as a result of artificial light irradiation. Journal of Photochemistry and Photobiology B: Biology 99: 144-149.

Sandoval-Torres, S.; Jomaa, W.; Marc, F.; Puiggali, J.R. 2010. Causes of color changes in wood during drying. For Stud China 12: 167-175.

Schwanninger, M.; Rodrigues, J.C.; Pereira, H.; Hinterstoisser, B. 2004. Effects of short-time vibratory ball milling on the shape of FT-IR spectra of wood and cellulose. Vibrational Spectroscopy 36: $23-40$.

Tuong; V.M.; Li, J. 2010. Effect of heat treatment on the change in color and dimensional stability of acacia hybrid wood. BioResource 5: 1257-1267.

Zhang, H.h.; Cui, Y.; Zhang, Z. 2013. Chemical treatment of wood fiber and its reinforced unsaturated polyester composites. Journal of Vinyl and Additive Technology 19: 18-24. 